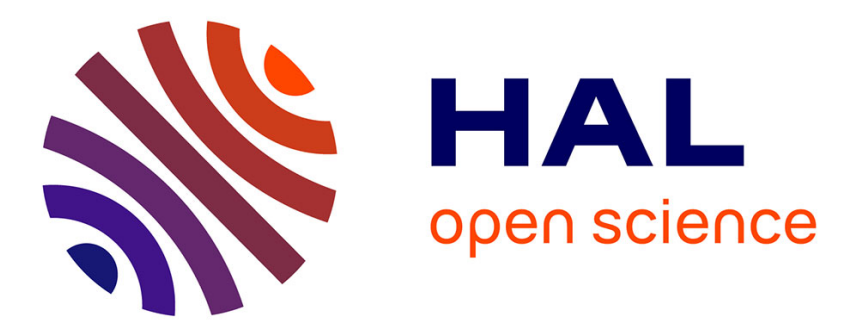

\title{
Policy instruments for decentralized management of agricultural groundwater abstraction: a participatory evaluation
}

\author{
A.G. Figureau, M. Montginoul, Jean-Daniel Rinaudo
}

\section{To cite this version:}

A.G. Figureau, M. Montginoul, Jean-Daniel Rinaudo. Policy instruments for decentralized management of agricultural groundwater abstraction: a participatory evaluation. Ecological Economics, 2015, 119, pp.147-157. 10.1016/j.ecolecon.2015.08.011 . hal-01272838

\section{HAL Id: hal-01272838 \\ https://hal.science/hal-01272838}

Submitted on 11 Feb 2016

HAL is a multi-disciplinary open access archive for the deposit and dissemination of scientific research documents, whether they are published or not. The documents may come from teaching and research institutions in France or abroad, or from public or private research centers.
L'archive ouverte pluridisciplinaire HAL, est destinée au dépôt et à la diffusion de documents scientifiques de niveau recherche, publiés ou non, émanant des établissements d'enseignement et de recherche français ou étrangers, des laboratoires publics ou privés. 


\title{
Policy instruments for decentralized management of agricultural
}

\section{groundwater abstraction: a participatory evaluation}

\author{
A.-G. Figureau ${ }^{\mathrm{a}, \mathrm{b},}$, M. Montginoul ${ }^{\mathrm{a}}{ }^{\mathrm{a}}$ and J.-D. Rinaudo ${ }^{\mathrm{b}}$ \\ ${ }^{a}$ Institut de Recherche en Sciences et Technologies de l'Environnement et de \\ l'Agriculture, UMR G-Eau, 361 rue Jean-François Breton, BP5095, 34196 Montpellier \\ Cedex 5, France \\ ${ }^{\mathrm{b}}$ Bureau de Recherches Géologiques et Minières, 1039 rue de Pinville, 34000 \\ Montpellier, France
}

\begin{abstract}
This paper proposes and analyses three policy instruments which can be used to enhance farmers' compliance with individual water allocations in a decentralized management context. Three regulation strategies are proposed for the case of groundwater allocations for irrigation: the first relies on economic instruments; the second is based on tools designed to promote prosocial behaviors; and the third combines assumptions from the first two approaches. They are evaluated through 16 scenario workshops involving 124 stakeholders and farmers in five French groundwater basins. Stakeholders' perceptions are analyzed, disentangling the ethical, economic, institutional, social and technical perspectives underlying the stakeholders' arguments for or against the proposed instruments for groundwater-use regulation. The analysis reveals a preference for the strategy that combines economic and social incentives.
\end{abstract}

\section{Keywords}

CPR, decentralized management, economic incentives, participatory approach, groundwater, irrigation, France

\section{Highlights}

- $\quad$ Three regulatory strategies were designed, combining economic and social incentives

- 16 scenario workshops were carried out involving 124 stakeholders in five French groundwater basins

- Economic incentives may be efficient if well designed, but they find little acceptance. 
Author-produced version of the article published in Ecological Economics, 2015, N¹19, p.147-157.

The original publication is available at http://www.sciencedirect.com

Doi: 10.1016/j.ecolecon.2015.08.011

- Social incentives are acceptable but their effectiveness depends on pre-existing community cohesion.

- Participatory evaluation methodologies enable the integrated evaluation of environmental policies.

*: corresponding author. Marielle Montginoul, IRSTEA, 361 rue Jean-François Breton, BP 5095, 34196 Montpellier cedex 5, France. Email : $\underline{\text { marielle.montginoul@irstea.fr }}$ 
Author-produced version of the article published in Ecological Economics, 2015, №119, p.147-157.

\section{Introduction}

Groundwater resources are increasingly being overexploited worldwide, owing to demographic growth, rising demand for agricultural products, technological progress in irrigated agriculture and the flexibility that groundwater use provides (Giordano and Villholth, 2007; Llamas and Martinez-Santos, 2005). Although intensive groundwater exploitation supported the development of a flourishing agricultural economy (Kuper et al., in press; Shah, 2008), it also generated significant negative impacts such as declining water tables, reduction of in-stream flows, the drying-up of springs, wetlands deterioration, land subsidence and sea-water intrusion (Llamas and Martinez-Santos, 2005; Schlager, 2006; Shah et al., 2003). Groundwater-management policies have been progressively developed to mitigate these impacts through a better control of groundwater abstraction. This requires shifting from an open-access regime to one of regulated abstraction. The total volume of water that can be abstracted is first 'capped': an overall water allocation is defined based on hydrogeological studies which estimate a sustainable yield, defined as the maximum level of abstraction that can be maintained over the long term without generating any significant ecological impact on the aquifer and its dependent ecosystems. This global allocation is then shared among a limited number of authorized water users. Individual users receive a specific volume that must not be exceeded, and which, depending on the national legal and regulatory framework, is associated with a licence, a concession or a use right. Such groundwater-management policies have already been implemented in a number of countries including several western states of the USA (Blomquist et al., 2004; Schlager, 2006), Australia (Ross and Martinez-Santos, 2009), Spain (Garrido et al., 2005), Chile (Hearne and Donoso, 2005) to mention only a few. More recently, similar policies have been advocated in European countries, in particular France (Figureau and al., 2012) and the UK (DEFRA, 2013).

The main challenge faced by water managers during this transition process consists of designing and implementing policy instruments which are likely to achieve the 
Author-produced version of the article published in Ecological Economics, 2015, №119, p.147-157.

targeted objectives in an ever-changing economic, climatic and hydrological environment. Because farmers are confronted by market and climate fluctuations, as well as unforeseen technical, environmental, personal and financial events, their demand is likely to vary from year to year, sometimes exceeding, sometimes falling below their individual allocations. The manager then needs to ensure that the sum of individual water uses remains within the limits of the total volume allocated to farmers (global allocation), i.e., that the excesses of some be offset by the moderation of others (overall compliance). The introduction of some flexibility into the allocation system is expected to yield economic benefits, as long as overall compliance is achieved.

To reach this double objective - flexibility and overall compliance - many countries have progressively abandoned the traditional command-and-control approach in favour of the devolution of responsibilities to Groundwater Users Associations (GWUA). The assumption underlying this evolution is that GWUAs can adapt general institutional rules to the local context, thereby increasing their technical and economic relevance as well as their social acceptability. This particularly applies to allocation rules: policy instruments aiming at increasing flexibility and ensuring overall compliance are likely to be more efficient if they are designed to accommodate specific features of the local context.

In this decentralized context, GWUAs can use a variety of policy instruments, including economic instruments and institutional arrangements. Typical economic instruments include negative incentives such as pricing, taxes, and penalties, or positive ones such as subsidies or payments. Scholars have proposed other theoretical instruments such as an ambient tax (Giordana, 2007), differentiated ambient tax (Lenouvel et al., 2011) or combined tax-and-rebate systems (Swierzbinski, 1994). Nevertheless, case studies from various parts of the world also report successful common resource regulations relying on institutional arrangements rather than economic instruments (Aoki, 2006; Lopez-Gunn, 2003; Ostrom, 1990; Ross and 
Author-produced version of the article published in Ecological Economics, 2015, №119, p.147-157.

Martinez-Santos, 2009; Van Steenbergen, 2006). A significant number of studies in experimental economics have demonstrated the effectiveness of policy instruments relying on other levers than financial motivations to reach sustainable resource management (Bochet et al., 2006; Cardenas, 2011; d'Adda, 2011; del Pilar MorenoSánchez and Maldonado, 2010; Murphy and Cardenas, 2004; Travers et al., 2011; Velez et al., 2010; Zafar, 2011). Such tools seek to promote communication between agents, to increase the transparency of agents' behaviours, and to facilitate internal agreements. Their objective is to reinforce trust, accountability, reputation effects and adherence to social norms.

Most of existing studies evaluating such instruments are based on quantitative approaches (such as experimental economics and field experiments) to measure the effectiveness of various instruments and to test implementation variants. They however do not help understanding contextual environmental, socio-economic and cultural factors which determined the observed behaviours. The qualitative approach presented in this paper aims at offering a better and deeper understanding of these factors. This knowledge gained may then help designing instruments which are better adapted to the local context, thus more likely to be accepted and implemented by agents (Rinaudo et al., 2012). The proposed approach is thus considered as complementary rather than competing with field experiments which involve real agents such as farmers, forest users, fishermen (Cardenas, 2011; d'Adda, 2011; del Pilar Moreno-Sánchez and Maldonado, 2010; Travers et al., 2011; Velez et al., 2010).

This paper presents an empirical assessment of contrasted regulation strategies using groups of stakeholders and farmers in five French groundwater basins. The main objective is to identify factors which could facilitate or act as barriers to the implementation of theoretically efficient policy instruments in a context of decentralized groundwater management. The remainder of this paper is organized as follows. Section 2 describes three contrasted regulation strategies which could be implemented to 
simultaneously increase water allocation flexibility and ensure overall compliance, in a fluctuating economic and climatic context. Section 3 presents the workshop methodology used for discussing these strategies, and case studies in which it has been applied. The main findings are presented in Section 4, highlighting factors which determine the effectiveness, social acceptability and practical feasibility of the three strategies. Section 5 concludes by summarizing the findings, discussing the advantages and limits of the participatory evaluation method used in this study.

\section{Three regulation strategies for managing groundwater-based abstraction for irrigation}

Three contrasted policy approaches are proposed and discussed in this paper: the first relies entirely on economic instruments; the second is based on tools designed to promote pro-social behaviors; and the third combines various assumptions from the first two approaches. These three strategies were then used as the basis for constructing policy scenarios, which were debated with stakeholders.

\subsection{Coupling economic incentives}

The first strategy discussed in this paper assumes that the most efficient way to influence individual behavior consists of changing the economic incentives through interventions which alter the costs and benefits of certain targeted actions. The underlying assumption is that individuals respond by adapting their decisions to maximize their individual pay-offs. Following scholars like Rapoport and Au (2001) and Sefton et al (2007), we propose to combine the use of a penalty with a reward. The penalty consists of a tax charged to farmers who exceed their allocation and is proportional to the over-pumping; it aims to discourage free-riding (excess pumping). The revenues from this penalty system are then redistributed among farmers who withdraw less than their entitlement, each one receiving a share proportional to their water saving. The reward encourages voluntary contributions to the public good 
(reduced abstraction). This combination is expected to lead to an optimal level of individual contribution (Sefton et al., 2007). Rewards are funded by revenues from penalties as suggested by Rapoport and $\mathrm{Au}$ (2001). The system is expected to meet both the flexibility objective (since farmers may exceed their allocation by paying the tax) and the overall compliance objective. By design, the amount of reward is not known in advance, since it depends on the choice of all other farmers. This uncertainty does not prevent farmers from taking sound decisions based on a comparison of the expected utility associated to different strategic choices. Given farmers' heterogeneity in terms of production functions, risk aversion and capacity to anticipate strategic behaviors, all farmers will not take the same decision in a similar context. If the analyst has perfect information on users, he can theoretically calculate the exact level of penalty that will ensure budget and water equilibrium. In practice, the level of penalty would probably be adjusted by trial and errors.

\subsection{Promoting pro-social behaviours}

An abundant literature, mainly drawing upon experimental economics, has shown the limitations of incentive-based approaches. It recognizes that individual behaviors are often influenced by non-economic motives, including adherence to social norms, ethical commitment, altruism, reciprocity and inequity aversion (d'Adda, 2011; Fehr and Gächter, 2000; Masclet et al., 2003; del Pilar Moreno-Sánchez and Maldonado, 2010; Rapoport and Au, 2001; Sefton et al., 2007; Travers et al., 2011). Such social preferences can be enhanced by policies designed to strengthen reputation effects, fairness, accountability, trust or moral inclusion.

The second strategy considered in this paper fundamentally seeks to exploit social preferences to promote pro-social behaviours, so as to meet the objectives of flexibility and overall compliance. The overarching objective is to "empower public-spirited motives" rather than only selfish preferences (Bowles, 2008) and to enhance social norms that can promote cooperative behaviours (Vatn, 2009). This strategy relies on 
two main pillars. The first consists of developing cooperation among farmers through reinforcing values such as reciprocity, solidarity and moral inclusion. The underlying assumption is that, each year, some farmers are likely to accept to relinquish part of their individual water allocation to help other farmers confronted by unusual situations. The volume they give back is made available to the GWUA, which in turn redistributes it to farmers who have an exceptional need for extra water. The internal redistribution follows general principles and rules which have been validated by the farm community; their practical implementation can however be modified each year to take into account specific events (climate extremes, market situation, pest attack, etc.). The GWUA acts as an interface between the giving and the receiving farmers, who do not interact directly, since interpersonal relationships may act as an impediment to solidarity. Another reason for preventing bilateral interaction and agreements is to avoid informal water trading, and the development of the accompanying "market mentality" (Titmuss, 1971). This internally anonymous reallocation should be facilitated by feelings of solidarity, reciprocity and trust, which are likely to exist among irrigators since they represent a community of shared interests. The success of this strategy necessitates increased communication between farmers, as shown by economic experiments conducted for similar natural resource management problems elsewhere (del Pilar Moreno-Sánchez and Maldonado, 2010 and Murphy and Cardenas, 2004; Travers et al., 2011).

The second pillar of this strategy is the control of free-rider behaviours, i.e., preventing farmers from breaking the agreed rules and unilaterally taking the decision to exceed their allocation. This can be done by disclosing information regarding individuals' decisions or actions to all members of the concerned community. The underlying hypothesis is that transparency increases moral incentives for users to comply with the allocation rules, since their individual behaviours are being observed by their peers: "any person can, through open contempt or intimidation, withhold another person from 
breaking the moral code" (Van Steenbergen and Shah, 2003). Non-compliance with social norms thus becomes socially costly. Such a tool has been tested in experimental economics and its positive effects on behaviour were demonstrated repeatedly (Fehr and Gächter, 2000; Masclet et al., 2003). However, some studies indicate that its effect varies from one community to another, being conditioned by the prior existence of a norm defining what constitutes virtuous behaviour (d'Adda, 2011; Travers et al., 2011). Its effectiveness likewise depends on how reputation matters within a community. Casari (2000) reports a centuries-old institution in place in the Italian Alps where users, by monitoring others, could report rule violations to a local court and receive money from fines. The principal risk is the emergence and propagation of a weak or even counterproductive social norm (poor contributions to the common good, widespread over-exploitation...) which may result in a race to the bottom (Zafar, 2011). The assumption that transparency is likely to enhance the farmers' individual compliance with internally-negotiated water allocations is supported by the evidence from real case studies worldwide (Lopez-Gunn, 2003; Ostrom, 2000; Shah, 2012; Van Steenbergen, 2006).

\subsection{Combining economic and social incentives}

The third strategy discussed in this paper combines the two sources of the human motivation to cooperate: the maximization of individual economic gains and of social utility (Kerr et al., 2012; Vatn, 2009). It consists of offering groups of farmers the opportunity to sign a contract (which we called a joint liability contract in our workshops) through which they mutualize their individual water allocations. Participation is voluntary. Farmers gain two benefits from entering a group: reduced GWUA fees (compared to remaining as individuals) and increased flexibility (since they can make any arrangements they wish within the group, whereas individuals must strictly comply with their individual allocations). However, if the group exceeds its water entitlement a collective fine is charged to each individual farmer, in proportion to 
the collective excessive pumping (joint liability). Finally, group members have access to detailed information on the volumes abstracted by each other member (through the combined use of smart meters and a web-based information system), which allows for mutual control.

This group contract is partly inspired by studies on team approaches and ambient policies that have been recognized as effective ways to enhance compliance, e.g., for non-point source problems (Romstad, 2003). It assumes that small group empowerment eases self-regulation and fosters social control and peer pressure. It corresponds to what Ostrom (1990) called "nested enterprises". One assumption is that agents have more information on their reciprocal actions than the controller (Isik and Sohngen, 2003; Romstad, 2003). Moreover, it is expected that farmers entering a group will generally belong to established social networks and are linked together by other ties than water allocation. This increases their propensity to abide by the rules, since playing cooperatively in the irrigation game ensures further benefits from other economics and social exchanges, as shown by Aoki (2006).

Moreover, the proposed group contract meets the conditions highlighted by Isik and Sohngen (2003) to enhance compliance: the contract (i) is performance-based, i.e., the group has an obligation for results; (ii) it is voluntary (farmers refusing to join a group keep their individual water allocations); (iii) it includes a flat-rate payment as an incentive to join; and (iv) it includes a performance-related incentive to remain a member.

\section{Methodology and case study}

The successful implementation of the three groundwater regulation strategies presented in the previous section will depend on a number of agricultural, hydrogeological, economic and social factors which may act as barriers or facilitating conditions. Because these strategies have not yet been implemented in the real world 
and thus cannot be studied ex-post, the only way to investigate these factors consists of involving concerned stakeholders in participatory ex-ante evaluation. This can be done by using experimental economics (Cherry and McKee, 2011), stated preference techniques such as choice experiments (Koundouri, 2004), or more qualitative approaches such as role-playing games (IIED, 1997; Roling and Wagemakers, 2000) and scenario workshops (Hatzilacou et al., 2007; Rinaudo et al., 2012). The scenario workshop methodology was selected for conducting this research for three main reasons. First, it can be used to elicit individual preferences for various policy alternatives; second, it allows the assessment of policy options using very different dimensions such as economic efficiency, environmental effectiveness, social justice and ethical considerations; third, it allows a confrontation of different viewpoints during the workshop, which helps participants to structure their analysis and defend their positions. The conceptual methodological framework and its operational implementation are presented in the following paragraph.

\subsection{Methodological framework}

The participatory evaluation method deployed in this study was inspired by earlier work in France, Portugal and Morocco (Rinaudo et al., 2012; Faysse et al, 2014). It consisted of organizing relatively short workshops (4-5 hours each) during which a small number of participants were asked to scrutinize the three alternative groundwater regulation strategies. Participants received in advance three short narrative scenarios describing a possible implementation of these strategies, at a time horizon ranging from 2020 to 2030. Scenarios were presented using a press release format, and for ease of understanding, were named as follows: "Penalties and Payments" (P\&P) for the strategy based on economic incentives, "Community Ties" for the strategy based on social incentives, and "Joint liability contract" for the mixed one. The 2030 time frame was purposely chosen to reflect the significant legal and institutional changes required 
before implementing them. That is why we chose to present the scenario "Community Ties" as the first one since it does not rely on any relevant legal or institutional change. A secondary objective was also to "detach" participants from the official positions they defend on a day-to-day basis in various social and political arenas, thereby reducing the risk of strategic behaviors.

In each case study, several groups of farmers and institutional stakeholders were involved. Although the scenario-workshop method usually mixes policy makers, business representatives, experts, and citizens, we decided to set up separate groups for the various public - institutional representatives of organizations involved in agricultural water management along with experts on the one hand, and farmers on the other hand. This methodological choice was adopted to overcome the mistrust which characterizes relationships between farmers and public-sector experts, in the current context of a controversial water-law reform. We also opted for smaller groups (five to fifteen persons) in contrast to the scenario groups described in the literature, where each workshop comprises between 25 and 40 persons (Hatzilacou et al., 2007).

The workshops consisted of six steps. Following a brief presentation of the research context and objectives, current groundwater management rules were reviewed and clarified if necessary, the objective being to construct a common representation of the initial situation before debating alternative scenarios (Step 1). We then presented a baseline scenario, depicting how groundwater management would evolve by 2020 , considering the progressive implementation of the new 2006 water law (Step 2). The three regulation scenarios were then successively introduced and discussed (Steps 3 to 5); and a general discussion was conducted to wrap up the workshop (Step 6). During Steps 3 to 5, each scenario was evaluated as follows: after an oral presentation of the scenario made by the research team, participants were asked to complete individual questionnaires (five questions per scenario) before any discussion could take place; the moderator then went around the table asking each participant to express his/her 
individual perception of the scenario, no discussion being allowed at that stage; this was followed by an open discussion during which participants debated their diverging opinions. The same sequence was repeated for each scenario. Discussions were digitally recorded.

The analysis was based on both a quantitative analysis of the questionnaires and on a qualitative analysis of the participants' views. Audio recordings of the workshops were transcribed to provide verbatim versions of the speeches. This enabled a database of individual stakeholder's arguments to be constructed. Each record in the database consists of a few sentences (quotes of stakeholders' exact wording); a short reformulation of the corresponding argument (written by the research team); and the stakeholder reference (name, date of the workshop). When a single individual repeated the same idea several times during a workshop, only one record was entered in the database, but several records were entered when different stakeholders expressed a similar idea, using different wording.

- The second step of the analysis consisted of grouping "individual arguments" corresponding to the same "statement". This analysis was repeated independently by two of the authors to control for the subjectivity inherent in this type of analysis. Each general statement was then characterized using three indicators. The first one indicates whether the statement supports or dismisses the scenario (some statements are neutral). The second indicator describes whether the statement refers to an economic, social, ethical, institutional or technical viewpoint. The third indicator is created by classifying statements according to the evaluation criteria referred to in the statement: (i) effectiveness, e.g., ability to meet the flexibility and global compliance objectives; (ii) acceptability to concerned parties; (iii) feasibility of implementation; and (iv) potential unintended effects. The results of this classification are presented in Tables 2 to 4 in the next section. 
- The database was finally used to estimate quotation frequencies for each general statement. The quantitative indicator selected is the percentage of workshops ( $\mathrm{X}$ out of the 16) where the statement was mentioned.

\subsection{The French context}

The study was conducted in France, in a context of the on-going water policy reform initiated by the 2006 water act. In the 1980 and 1990s, groundwater development has taken place in an institutional setting that imposed few if any limits on groundwater use, groundwater-use licenses being almost systematically granted to requesting farmers. As abstractions rose and environmental problems emerged, the State reacted by enforcing temporary pumping restrictions. The increasing frequency of such restrictions led to a new approach, embodied in the 2006 water law ${ }^{1}$, which consists of imposing a ceiling on groundwater abstraction in overexploited aquifers. This ceiling, expressed as an authorized volume per year, is defined in such a way that groundwater-dependent ecosystems can remain in good ecological condition, under normal climatic conditions, i.e., in four out of every five years. The authorized volume is then apportioned by the State among economic sectors (urban supply, industry, agriculture). The volume allocated to agriculture is officially assigned to the newly formed Groundwater Users' Associations (GWUA- Organisme Unique de Gestion Collective in French) which are made responsible for apportioning it among farmers. GWUAs must develop their own rules for defining individual water entitlements.

At the time of the workshops (2013), GWUAs had just been established and national farmers' organizations were starting to explore possible ways for establishing water allocation rules within GWUAs. There was an emerging consensus around several assumptions which were incorporated in all our scenarios. The first one is that each

${ }^{1}$ Loi n ${ }^{\circ}$ 2006-1772 du 30 décembre 2006 sur l'eau et les milieux aquatiques Journal Officiel de la République Française, n³03 du 31 décembre 2006 
Author-produced version of the article published in Ecological Economics, 2015, №119, p.147-157.

farmer will receive an individual water entitlement valid for a specific period of time (15 years), based on a grandfathering rule moderated by agricultural criteria (crops, soils ...). The second is that monitoring of individual farmers' groundwater use will not represent a major challenge, owing to the anticipated rapid dissemination of new technologies such as automated meter-reading and telemetry. A corollary is that information on groundwater use can easily be made accessible through a wide range of actors via internet technologies. The fourth assumption is that the legal status of the GWUAs will be strengthened, providing them with a clear legal framework for developing water allocation rules and enforcement mechanisms. Accordingly, they will be accountable to the State for ensuring that the authorized volume they receive is not exceeded. Departing from that context, the three groundwater regulation strategies described in Section 2 represent plausible options for implementing groundwater policy reform at the GWUA level.

\subsection{Case studies and operational implementation}

Five French groundwater basins characterized by overexploitation were selected for the organization of scenario workshops. They are representative of the diversity of agricultural products (industrial vegetables, fruits, cereals ...) and hydrogeological situations (karstic or alluvial aquifer, inertias of a few months to several years ...), as depicted in Figure 1 and Table 1.

Before organizing the workshops we conducted a series of individual interviews with key stakeholders in each case study, with three main objectives: 1) to obtain institutional clearance from the local farmers' organizations to apply our work on their basin, 2) to collect the information required to adapt scenario narratives to the local context; and 3) to access to the local farmers' directory to prepare the selection of participants. A total of 16 workshops, involving 124 participants (44 institutional representatives or experts and 80 farmers), were organized in 2013. 
Author-produced version of the article published in Ecological Economics, 2015, №119, p.147-157. The original publication is available at http://www.sciencedirect.com

Doi: 10.1016/j.ecolecon.2015.08.011

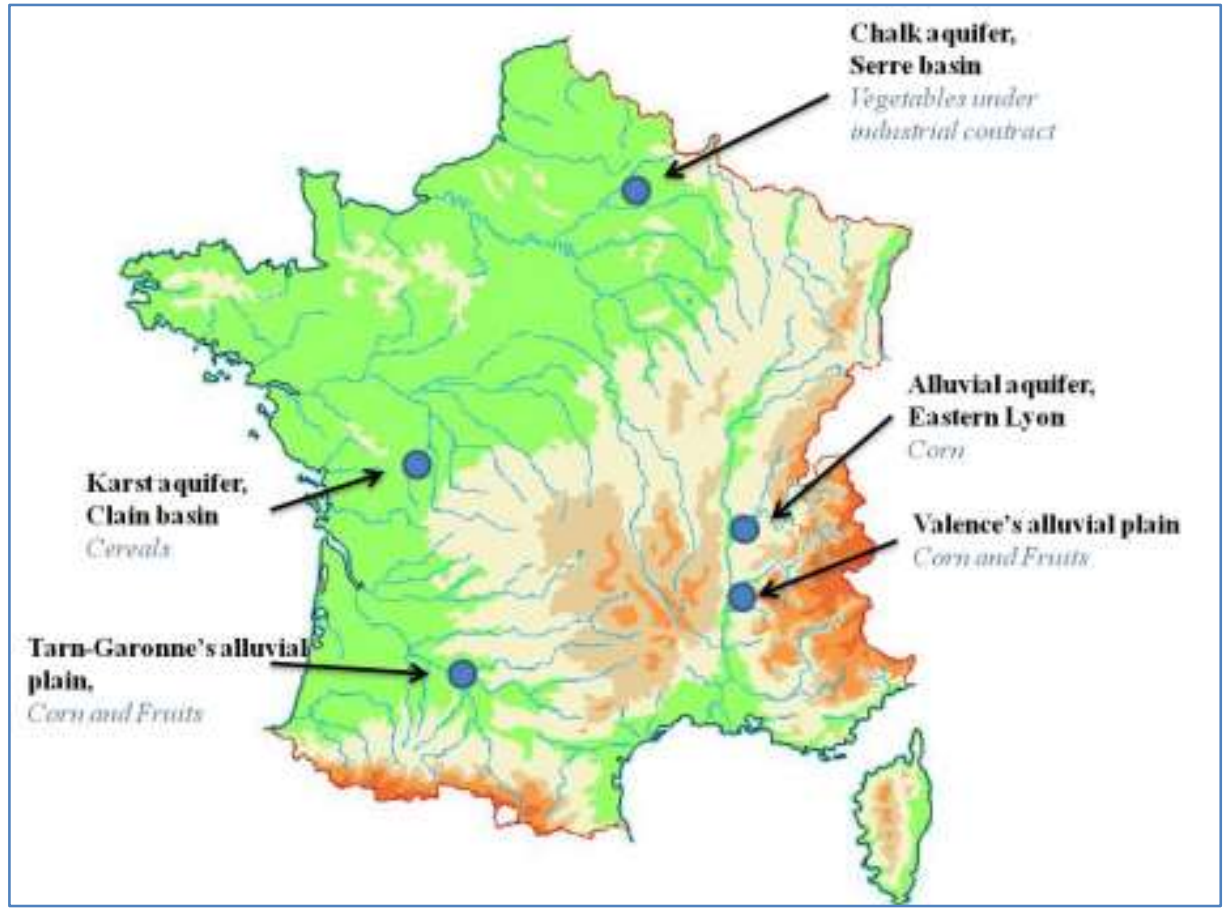

Figure 1: Location and main features of the five case studies in France

\section{Table 1 : Sites' main features and comparison}


Author-produced version of the article published in Ecological Economics, $2015, N^{\circ} 119$, p.147-157.

\begin{tabular}{|c|c|c|c|c|c|c|c|c|}
\hline & $\begin{array}{l}\text { Hydro- } \\
\text { geology }\end{array}$ & $\begin{array}{c}\text { Basin } \\
\text { scale } \\
\left(\mathbf{k m}^{2}\right)\end{array}$ & $\begin{array}{r}\mathrm{Do} \\
\text { Alternative } \\
\text { resource }\end{array}$ & $\begin{array}{l}\text { Agricultural } \\
\text { production } \\
\text { and Irrigated } \\
\text { area }\end{array}$ & $\begin{array}{l}\text { Agricultural } \\
\text { groundwater } \\
\text { abstraction } \\
\quad(\mathbf{M m 3})\end{array}$ & Current management & Current scarcity level & Main insights from workshops \\
\hline $\begin{array}{l}\text { SERRE } \\
\text { BASIN }\end{array}$ & $\begin{array}{l}\text { Chalk } \\
\text { aquifer }\end{array}$ & 1630 & $\begin{array}{l}\text { Very } \\
\text { limited } \\
\text { surface } \\
\text { water }\end{array}$ & $\begin{array}{l}\text { Vegetables for } \\
\text { industrial use, } \\
\text { cereals } \\
4000 \text { ha } \\
2,5 \% \text { UAA }\end{array}$ & 5,6 & $\begin{array}{c}\text { Individuals withdrawals } \\
\text { State-centralized management } \\
\text { Flow authorization } \\
\text { Theoretic random control \& } \\
\text { fines } \\
\text { Quotas in case of crisis }\end{array}$ & $\begin{array}{l}\text { Rare restrictions } \\
\text { Aquifer not overexploited } \\
\text { Uncertainty about the } \\
\text { conversion of } 8000 \text { ha of } \\
\text { former non irrigated crops }\end{array}$ & $\begin{array}{l}\text { - Maintaining the regional agroindustry- } \\
\text { based economy is a main concern } \\
\text { - Farmers are attached to an individual } \\
\text { farm management in order to remain } \\
\text { flexible and adapt to industrial contracts }\end{array}$ \\
\hline $\begin{array}{c}\text { VALENCE' } \\
\text { S } \\
\text { ALLUVIAL } \\
\text { PLAIN }\end{array}$ & $\begin{array}{l}\text { Alluvial } \\
\text { aquifer }\end{array}$ & 480 & $\begin{array}{c}\text { Dense } \\
\text { surface } \\
\text { irrigation } \\
\text { networks }\end{array}$ & $\begin{array}{c}\text { Corn, fruits, } \\
\text { vegetables } \\
9800 \mathrm{ha} \\
40 \% \text { UAA }\end{array}$ & 5 & $\begin{array}{c}\text { Individual withdrawals } \\
\text { State-centralized management } \\
\text { Flow authorization } \\
\text { Theoretic random control \& } \\
\text { fines } \\
\text { Time restrictions in case of crisis }\end{array}$ & $\begin{array}{l}\text { Quite frequent restrictions } \\
\text { Aquifer not overexploited } \\
\text { Low users information } \\
\text { Expected reduction for 2017: } \\
40 \%\end{array}$ & $\begin{array}{l}\text { - Farmers are not well-informed about } \\
\text { water reform } \\
\text { - Water scarcity is a recent issue and } \\
\text { reflection is "immature" } \\
\text { - Debates focused on water allocation } \\
\text { process rather than the enforcement } \\
\text { problem }\end{array}$ \\
\hline $\begin{array}{l}\text { EASTERN } \\
\text { LYON } \\
\text { AQUIFER }\end{array}$ & $\begin{array}{l}\text { Fluvio- } \\
\text { glacial } \\
\text { corridors }\end{array}$ & 400 & $\begin{array}{c}\text { No surface } \\
\text { water }\end{array}$ & $\begin{array}{l}\text { Cereals and } \\
\text { oil-and-protein } \\
\text { crops } \\
7000 \text { ha } \\
35 \% \text { UAA }\end{array}$ & 9 & $\begin{array}{l}\text { Collective withdrawals and } \\
\text { supply network } \\
\text { Flow authorization } \\
\text { Control and fines } \\
\text { Time and flow restrictions in } \\
\text { case of crisis }\end{array}$ & $\begin{array}{l}\text { Steady water table lowering } \\
\text { Aquifer not overexploited } \\
\text { Low users information } \\
\text { Expected reduction for 2017: } \\
20 \%\end{array}$ & $\begin{array}{l}\text { - Farmers are not well-informed about } \\
\text { water reform implications } \\
\text { - The historical collective management is } \\
\text { an obstacle to discussing alternative } \\
\text { management ways } \\
\text { - Institutional representatives are } \\
\text { convinced of the effectiveness of social } \\
\text { control and agreements between farmers }\end{array}$ \\
\hline $\begin{array}{c}\text { TARN-ET- } \\
\text { GARONNE' } \\
\text { S } \\
\text { ALLUVIAL } \\
\text { PLAIN }\end{array}$ & $\begin{array}{c}\text { Terraced } \\
\text { aquifer in } \\
\text { alluvial } \\
\text { plain }\end{array}$ & 940 & $\begin{array}{c}\text { Dense } \\
\text { surface } \\
\text { irrigation } \\
\text { networks }\end{array}$ & $\begin{array}{l}\text { Orchards, } \\
\text { cereals } \\
50000 \text { ha } \\
25 \% \text { UAA }\end{array}$ & 29 & $\begin{array}{c}\text { Individual withdrawals } \\
\text { State-centralized management } \\
\text { Model-based authorized } \\
\text { volumes, but ineffective } \\
\text { Theoretic random control \& } \\
\text { fines Time restrictions in case of } \\
\text { crisis }\end{array}$ & $\begin{array}{l}\text { Yearly crisis and restrictions } \\
\text { Users' low awareness of } \\
\text { scarcity } \\
\text { Expected reduction for } 2017 \text { : } \\
\text { from } 20 \text { to } 80 \%\end{array}$ & $\begin{array}{l}\text { - Stakeholders express a need for a fairer } \\
\text { water allocation } \\
\text { - Institutional representatives express a } \\
\text { need for a more binding management } \\
\text { - Farmers are attached to their individual } \\
\text { liberties and reject transparency and } \\
\text { collective management }\end{array}$ \\
\hline $\begin{array}{l}\text { CLAIN } \\
\text { BASIN }\end{array}$ & $\begin{array}{l}\text { Highly } \\
\text { reactive } \\
\text { karstic } \\
\text { aquifer }\end{array}$ & 3200 & $\begin{array}{l}\text { Very } \\
\text { limited } \\
\text { surface } \\
\text { water }\end{array}$ & $\begin{array}{c}\text { Cereals } \\
28000 \text { ha } \\
11 \% \mathrm{UAA}^{\mathrm{a}}\end{array}$ & 25 & $\begin{array}{c}\text { Individual withdrawals } \\
\text { State-centralized management } \\
\text { Annual authorized volume } \\
\text { Accurate groundwater } \\
\text { monitoring } \\
\text { Real-time groundwater } \\
\text { information to users } \\
\text { Theoretic random control \& } \\
\text { fines (unused) } \\
\text { Weekly volumes in case of crisis }\end{array}$ & $\begin{array}{l}\text { Yearly crisis and restrictions } \\
\text { Users' high awareness of } \\
\text { scarcity } \\
\text { Expected abstraction } \\
\text { reduction for } 2017: 50 \%\end{array}$ & $\begin{array}{l}\text { - Stakeholders are highly informed and } \\
\text { used to debate on water management } \\
\text { - They fear that financial incentives } \\
\text { increase injustices } \\
\text { - Stakeholders show interest in collective } \\
\text { organization that has been successfully } \\
\text { experienced at times }\end{array}$ \\
\hline
\end{tabular}




\section{Results}

\section{$3 \quad 4.1$ Overview}

4 The three proposed policy options triggered contrasting reactions from workshop

5 participants. In brief, the Payment and Penalty (P\&P) scenario was heavily criticized;

$668 \%$ of the recorded statements dismiss and oppose the scenarios (Figure 2). By

7 contrast, the "Joint Liability Contract" and the "Community Ties" scenarios were

8 perceived as more desirable options, with respectively $37 \%$ and $48 \%$ of individual

9 statements dealing with risks and drawbacks (Figure 2). Note that the Community Ties

10 scenarios generated fewer discussions (86 statements versus 204 / 198), probably

11 because it was considered to be closer to the current policy than the other two scenarios.

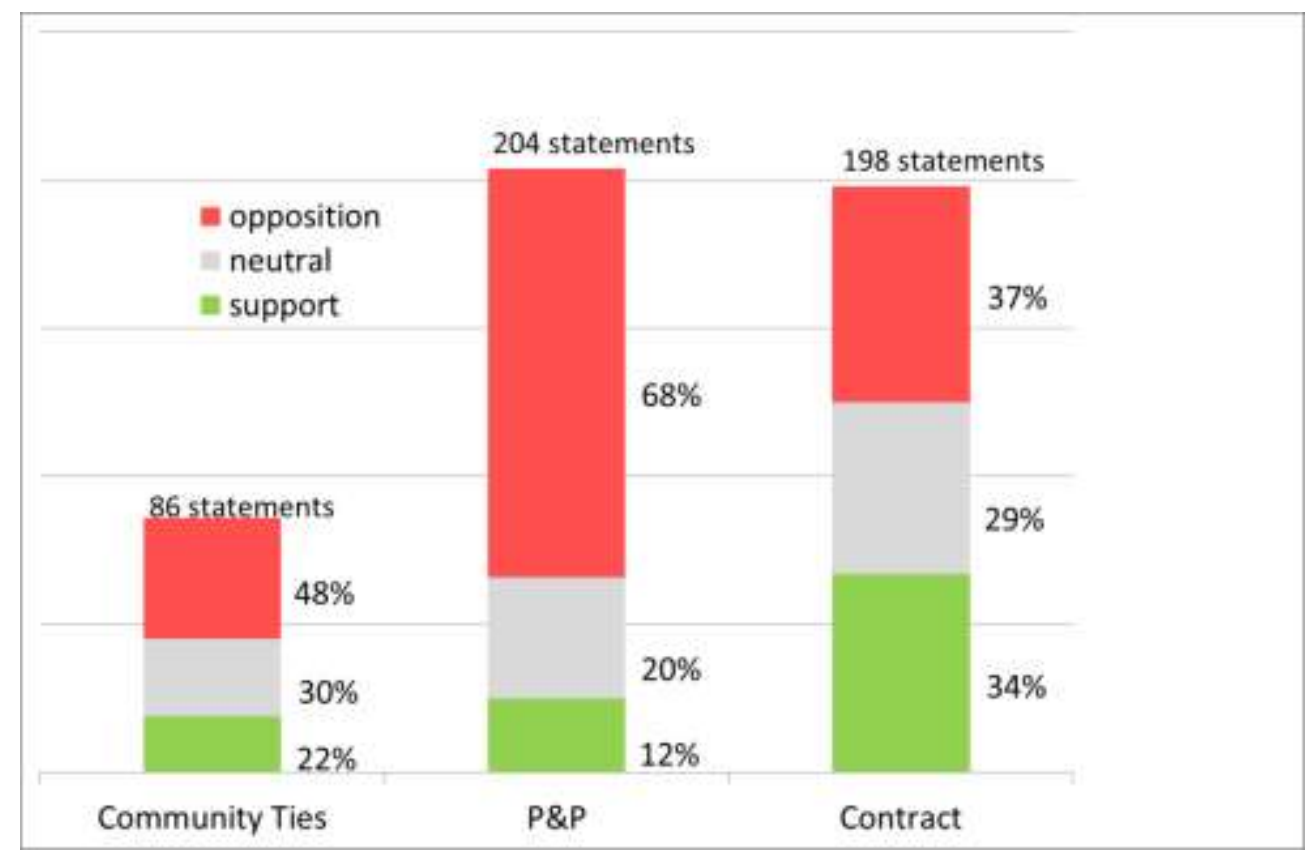

Figure 2: Distribution of statements into three categories (opposition, support or neutral) for each of the scenarios

This first analysis was deepened by investigating why each scenario is supported or opposed by the workshop participants. The result of this analysis is depicted in Figure 3. 
Author-produced version of the article published in Ecological Economics, 2015, №119, p.147-157.

Opposing or supporting statements are grouped into three categories (effectiveness, acceptability, feasibility). For each of these categories, we then calculate a support indicator $\mathrm{I}_{\text {sup }}$ (the number of supporting statements divided by the sum of supporting and opposing statements) and an opposition indicator $\mathrm{I}_{\mathrm{opp}}$ (the number of opposing statements divided by the sum of supporting and opposing statements). The support and opposition to each scenario is then depicted using two three-dimensional graphs. Figure 3 shows that the Joint Liability Contract is supported (and opposed) by statements referring to its effectiveness, acceptability and feasibility alike. By contrast, statements supporting the Community Ties scenario are mainly based on its perceived effectiveness while opposition is rooted in a negative perception of its acceptability and feasibility of implementation. The opposition to the $\mathrm{P} \& \mathrm{P}$ scenario is based on statements referring to all three dimensions (acceptability, effectiveness, and feasibility) while the few supporting statements address its perceived effectiveness.

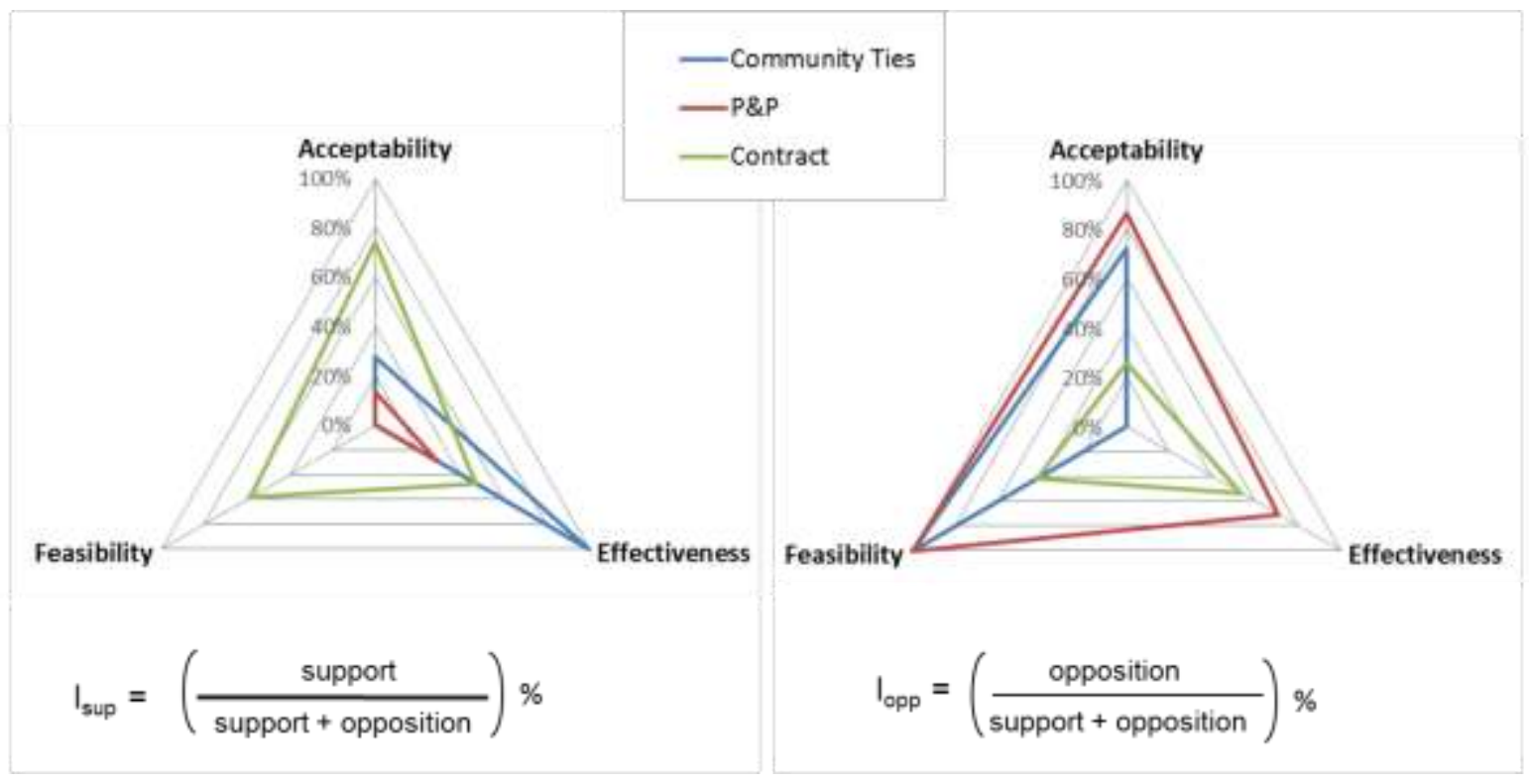

Figure 3: Support and opposition to the scenarios according to perceived acceptability, effectiveness and feasibility of implementation 
Author-produced version of the article published in Ecological Economics, 2015, №119, p.147-157. The original publication is available at http://www.sciencedirect.com

Doi: 10.1016/j.ecolecon.2015.08.011

Another interesting result is that the workshop participants were able to analyze each scenario from very diverse points of view - economic (35\% of the total number of statements quoted), technical (24\%), social (21\%), ethical (12\%) and institutional (8\%). The nature of the discussions triggered by each scenario significantly differs in terms of contents (Figure 4). The Community Ties scenario, which is closer to the current situation than the other two, is mainly discussed in technical terms ( $42 \%$ of statements). The P\&P scenario is mainly discussed in economic terms (51\% of statements), and to a lesser extent by looking at social and ethical issues. The Joint Liability Contract scenario mainly generates discussions on social issues.

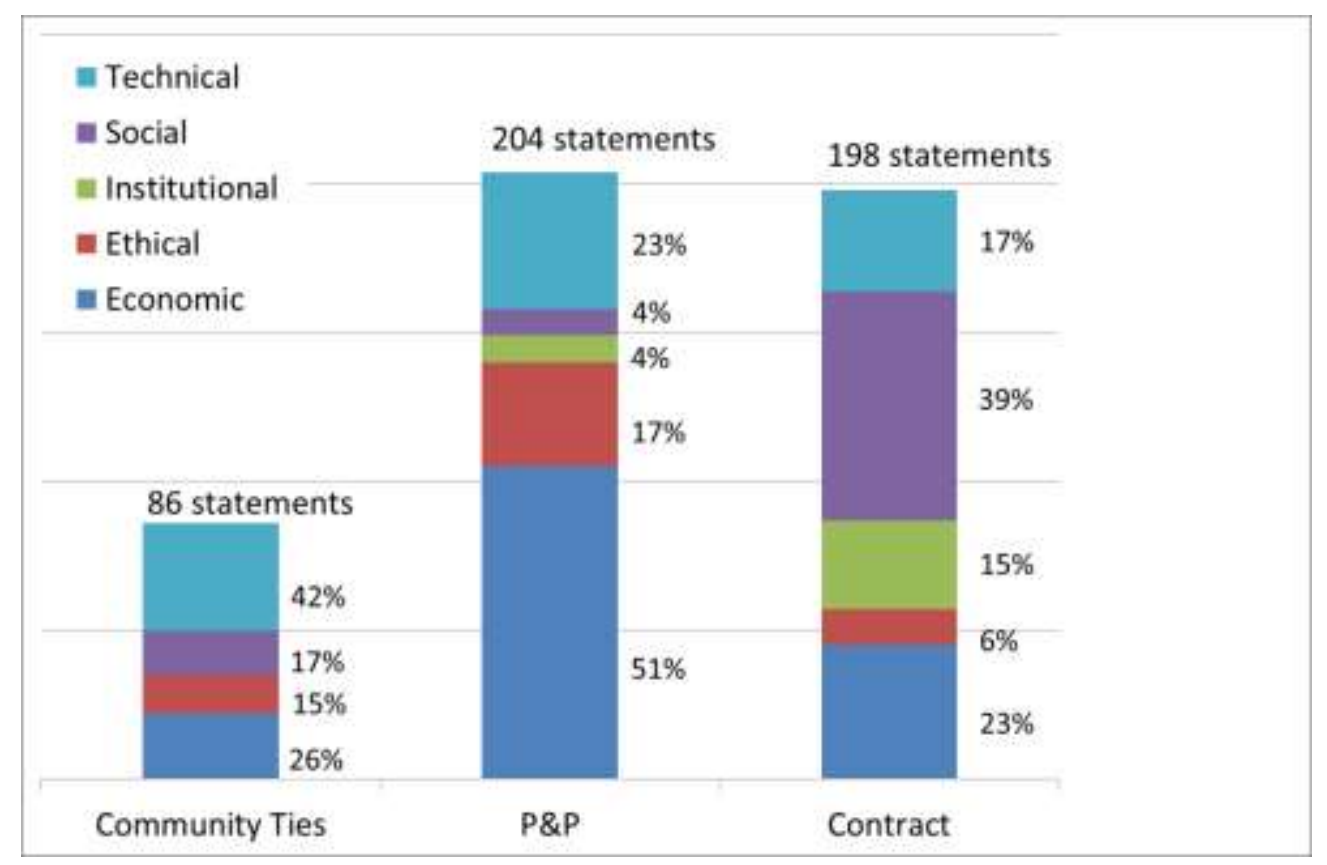

Figure 4: Distribution of statements according to underlying viewpoint (economic, social, technical, ethical, and institutional)

In the following paragraphs, we present a detailed analysis of the nature of the statements underlying Figures 2, 3 and 4. They are presented by scenario, using tables which provide a reformulation of the main statements as well as the number of workshops (out of 16) where they were expressed at least once.

\subsection{Perception of the Community Ties strategy}


Overall, a majority of workshop participants consider this strategy to be an

improvement compared to the current situation, in particular because they see it as empowering farmers, promoting true self-regulation and reducing state interference in what they consider a strictly agricultural issue. However, a closer analysis of statements expressed during the workshops (Table 2) reveals that, in spite of this overall positive appreciation, some participants were very critical of the two main components of this strategy, namely transparency and voluntary reallocation at the beginning of the season.

Concerning transparency, a majority of farmers (57\%) declare in the individual questionnaire that they do not believe that making water abstraction data publicly available will significantly increase overall compliance. Many recognize that information disclosure may help them decide to skip an irrigation application when the impact on yield is limited. But this impact will remain marginal and over abstraction is still expected to take place in particular during drought years. Institutional stakeholders are of a different opinion, with $64 \%$ declaring that transparency will promote responsible behaviors. In their opinion, information disclosure will also help identifying unused volumes of water, thus facilitating the identification of possible voluntary and temporary reallocations by the GWUA.

The proposed transparency triggers strong opposition from participants on ethical grounds. The disclosure of individual information on water use is considered to be an infringement on individual liberty. The self-monitoring and self-policing principles underlying transparency are criticized, participants fearing that they would generate a climate of suspicion, inevitably resulting in increased social tensions. Table 2 reveals the diversity of opinions concerning what could be considered as acceptable practice in terms of the disclosure of individual information.

The second pillar of the "Community Ties" strategy consists of entrusting the GWUA with the organization of a voluntary-based water-reallocation process at the beginning of the growing season. Overall, workshop participants adhere to the 
philosophy underlying the proposed reallocation mechanism, mainly because it assumes reciprocity and solidarity within the farming community. They insist on the fact that no bilateral exchanges should be allowed, the GWUA systematically playing the role of intermediary between anonymous donors and receivers. They say that this is needed to avoid the emergence of an informal water market which would inevitably transform mentalities and run against to the collaborative spirit underlying this strategy.

However, although agreeing upon the ideal that it represents, they express concerns about its effectiveness and feasibility. They observe that farmers remain very individualistic in their decisions and that few will be willing to give back some water to the GWUA. They suggest that the establishment of agreed rules defining how water is redistributed will be difficult, and possible only within small groups of farmers, asserting that prior acquaintance is essential to making such a pro-social regime successful. They also stress that effective reallocation will be feasible only in groundwater basins characterized by significant heterogeneity in terms of weather, soils, cropping systems and farming systems. It should be made clear that the "use it or lose it" principle will not apply and that farmers giving back part of their allocation will not suffer from a reduction of their individual allocations in the following year. Overall, $50 \%$ of farmers and $72 \%$ of institutional stakeholders declare in the questionnaire that, if implemented, this voluntary reallocation procedure would improve the farmers' situation by providing more flexibility in water use.

\subsection{Payments \& Penalties}

Most participants express a negative judgment concerning the P\&P strategy (Figure 2). They are mainly concerned about the effectiveness of the proposed mechanism (Figure 3): $75 \%$ of participants declare that $\mathrm{P} \& \mathrm{P}$ is not likely to increase overall compliance ( $70 \%$ of institutional stakeholders and $77 \%$ of farmers). Table 3 reveals the diversity of statements given by the participants to support such opinions. Participants recommended adjusting the level of the financial penalty to local economic, hydrologic 
Author-produced version of the article published in Ecological Economics, 2015, №119, p.147-157.

and climatic conditions. The level should be higher than the marginal value of water in normal climatic years, but not be too high to avoid the risk of farm bankruptcy, in particular during drought years when some farmers need to save their permanent crops. The choice of the penalty level should be based on a tradeoff between efficiency and long term farm viability objectives. Farmers also say that the uncertainty attached to the level of payment might act as a barrier refraining farmers from choosing a water conservation strategy. This uncertainty is inherent to the proposed instrument since the

112 level of payment depends on the total amount collected from those exceeding their 113 quota (uncertain) and the number of farmers reducing water use below their authorized 114 quota (uncertain).

115 Another factor likely to limit the effectiveness of the instrument is the inflexible nature of farm production choices (at least in the short term). Many farmers say they cannot shift from an intensive water use to a water conservation strategy because many investments in irrigation equipment are not yet amortized. These arguments are supported by the results of the questionnaire where $51 \%$ of farmers declare that, if the $\mathrm{P} \& \mathrm{P}$ were implemented, they would probably not change their practices to obtain a payment; $54 \%$ declare that they would consider exceeding their water allocation and be ready to pay a penalty. A minority of farmers (28\%) expressed their interest in a water saving strategy. Altogether, this suggests that the P\&P system might not ensure overall compliance since only a limited number of farmers would reduce abstractions while the majority would exceed their individual shares. participants to be opposed to the moral, social and ethical values of the farming community. Firstly, some participants consider that this "carrot and stick" strategy

129 stigmatizes farmers by treating them as unable to comply with their allocations. This 130 feeling is particularly strengthened by the fact that the policy instruments (in our 131 scenario) do not apply to other sectors. A second acceptability argument relates to 

endowed with excessive water allocations will benefit from undue payments, without making any significant water-saving efforts. The payment would thus strengthen existing illegitimate rents by giving them a monetary value. The second main argument is that $\mathrm{P} \& \mathrm{P}$ introduces a financial dimension into water management, which does not exist in the current situation. It also strengthens the feeling of private appropriation of water, since farmers not fully using their entitlement are financially compensated for it. The third is an opposition to being paid for stopping production, whereas they consider that their mission is to produce as much as possible, to feed the world. effects. They fear that the $\mathrm{P} \& \mathrm{P}$ will significantly modify production choices at the regional level, possibly disturbing the supply side of agro-industry and regional economies. The penalty is also expected to lead to a resurgence of illegal behaviors (tampering with water meters, illegal wells). Last but not least, the penalty could have a crowding-out effect on pro-social behaviors, reducing the intrinsic motivation to limit their use of water; by paying a penalty, some farmers might consider that they purchase the moral right to exceed their quota and increase total abstraction, the fine becoming a price (Gneezy and Rustichini, 2000). This could result in an overall increase in water

150 abstraction, with possible concentration in specific areas, generating environmental 151 impacts.

A number of improvement suggestions are formulated: the first consists of keeping the penalty but allocating the revenues to collective projects such as the development of new resources. Another suggestion is to replace the financial system with a carry-over system, in which farmers not using their quota in a given year could use it during the

156 next year, while those exceeding their quota would have a reduced allocation for the 157 next year. 
Author-produced version of the article published in Ecological Economics, 2015, №119, p.147-157.

Overall, the contract option is appealing to farmers because it is based on a voluntary decision and conveys a positive image of a responsible farming community capable of self-organizing. It is considered to be in line with the social and ethical values of the farming community. Two thirds of workshop participants believe that this regulation strategy is likely to achieve the overall compliance objective. Institutional stakeholders are particularly confident in the farmers group's capacity to comply with their water-use objective if water allocation is mutualized (86\%). The farmers themselves expressed a more balanced view point: $56 \%$ think the contract will be effective in ensuring compliance while $39 \%$ have the opposite opinion. Table 4 gives the main statements emerging from debates and illustrates the opposition between these two different points of view.

A majority of participants agree that the contract will increase flexibility for farmers opting for it. For instance, they quote analogous existing approaches for joint ownership and management of machinery and small private surface-water reservoirs. Mutualizing individual groundwater allocation is also seen as insurance mechanism, allowing a sharing of the risks associated with inter-annual variability of water availability and crop-water requirements. However, it is expected that only a limited percentage of farmers will sign a contract, for several reasons: (1) the incentives to enter a group are not judged sufficient (reduced GWUA membership fees); (2) the fact that the penalty is higher for groups than for individuals will discourage farmers willing to cooperate; (3) an individualistic mentality still prevails in agriculture and farmers are reluctant to mutualize production factors; (4) owing to limited farm heterogeneity, the number of farmers having a real interest in mutualizing their resources to increase flexibility and reduce risk is not significant; and (5) there is a real risk of non-compliance during

183 drought years, with associated economic (penalty) and social risks (conflict within the group). 
A number of suggestions were formulated to improve the probability that the

186 contract would be adopted and lead to increased flexibility and overall compliance.

187 Rules should be formally established within the group. It was recommended that an

188 external group facilitator be involved, hired by the GWUA, who could advise and

189 support the group in solving internal conflicts. The facilitator would also assist the

190 group in modifying the rules to cope with unforeseen situations and events (climate,

191 market, pest attack, personal event, etc.). Overall, the mixed opinions about the

192 proposed contract are confirmed by the farmers' stated willingness to engage in such a

193 contract: $43 \%$ declared that they would be willing to sign while $46 \%$ would not $(11 \%$

194 have no opinion). 
Author-produced version of the article published in Ecological Economics, 2015, №119, p.147-157.

\section{Discussion and conclusion}

In a context of water-policy reform, our work was aimed at exploring and evaluating contrasted strategies of decentralized groundwater management. We explored three strategies that GWUA might consider developing in order to prevent farmers from exceeding their allocations while trying to cope with climate variability and other sources of environmental and economic uncertainties. The first is based only on social incentives, the second only on economic incentives and the third strategy combines both.

From a policy perspective, the discussions which took place during workshops stressed that shifting from an open-access to a regulated groundwater exploitation regime will generate significant discontent in the farming community. Identifying the factors which determine the acceptability of alternative groundwater regulation strategies is therefore of very high importance. The method and the case study presented in this paper represent a first contribution to this issue. The results obtained also show

210 the preference of French stakeholders for policy instruments aiming at strengthening 211 social incentives rather than economic ones. The "Payment and Penalty" strategy is 212 generally rejected, while the "Community Ties" and the "Joint Liability Contract" 213 scenarios obtain greater support. However, there is some contradiction between the

214 dominant philosophical stance in favor of pro-social behaviors and the repeated assertions that, in real life, farmers think and act in a very individualistic manner,

216 following their self-interest rather than ethical principles and objectives. There is a need

217 to assess the relative weight of these two sources of individual motivations in order to 218 predict what the resulting behaviors are likely to be. Other methods, such as field 219 experiments, should be deployed to reach this scientific objective. Another open 220 question is whether these results can be extrapolated to other similar national contexts, such as Italy or Spain. Answering this question is crucial to providing sound 
recommendations to EU policy makers but it requires additional field work in different

economic, environmental and regulatory contexts.

From a methodological perspective, our research shows that the added value of participatory approaches resides in allowing the evaluation of policy options which consider a wide range of viewpoints. In our five case studies, the farmers demonstrated their ability to scrutinize the proposed strategies in terms of effectiveness, acceptability and feasibility of implementation. Their arguments were diverse, referring to the social, institutional, technical, and ethical dimensions of the problem. The value of comparing theoretical instruments with stakeholders' knowledge also lies in the fact that they are able to anticipate operational constraints, and identify conditions and factors that would foster or hinder their implementation. There are of course a number of limitations associated to the methodology: the opinions expressed can be characterized by cognitive and strategic biases. Many findings are contingent to the design of the theoretical instrument presented and they may be affected by the incomplete information provided in the narrative scenario description. Our experience also shows that workshop participants do not all share the same understanding of how the proposed policy instruments will impact farmers' behavior. Although they intuitively guess that strategic behavior may determine the outcome of the groundwater abstraction game, they cannot reliably predict what the outcome is likely to be. Results obtained with such participatory approaches should therefore be considered as complementary to those of economic modeling and experimental approaches. They cannot replace these more standard and quantitative approaches, such as framed field experiments which are considered to be a relevant approach for deepening the analysis presented in this paper. They represent the next step in our research. 
Author-produced version of the article published in Ecological Economics, 2015, N¹19, p.147-157.

The original publication is available at http://www.sciencedirect.com

Doi: 10.1016/j.ecolecon.2015.08.011

\section{Acknowledgments}

249 This work was financially supported by ONEMA as part of the Water Cap \& Trade

250 project ( Era Net program on Integrated Water Resources Management ); by the Rhône

251 Méditerranée Corse Water Agency (for the Drôme and East Lyonnais case studies); and

252 by the Carnot program of the National Research Agency (Ph.D grant of A.G. Figureau).

253 We thank Patrice Garin, Olivier Petit, Sophie Thoyer and Stephano Farolfi for fruitful

254 discussions of an earlier version of this paper. We also acknowledge the very useful and

255 relevant contributions of two anonymous reviewers. All errors and omissions remain

256 our responsibility.

\section{References}

Aoki, M. 2006. Fondements d'une analyse institutionnelle comparée: Editions Albin Michel.

Blomquist, W., E. Schlager and T. Heikkila 2004. Common Waters, Diverging Streams: Linking Institutions and Water Management in Arizona, California, and Colorado. Washington DC: Resources for the Future Press.

Bochet, O., T. Page and L. Putterman 2006. Communication and punishment in voluntary contribution experiments. Journal of Economic Behavior \& Organization 60: 11-26. doi: 10.1016/j.jebo.2003.06.006

Bowles, S. 2008. Policies Designed for Self-Interested Citizens May Undermine 'The Moral Sentiments' Evidence from Economic Experiments. Science 320: 1605-1609.

Cardenas, J. C. 2011. Social Norms and Behavior in the Local Commons as Seen Through the Lens of Field Experiments. Environmental \& Resource Economics 48: 451-485. doi: 10.1007/s10640-0109452-8

Casari, M. 2000. Emergence of endogenous legal institutions : the rural charters in northern Italy. Social Sciences working paper 1105.

Cherry, T. L. and M. McKee 2011. Experimental Methods and Environmental and Natural Resource Policy. In Research Tools in Natural Resource and Environmental Economics, eds. A.A. Batabyal and Peter Nijkamp, 307-339: World Scientific Publishing Company Pte Limited.

d'Adda, G. 2011. Motivation crowding in environmental protection: Evidence from an artefactual field experiment. Ecological Economics 70: 2083-2097. doi: 10.1016/j.ecolecon.2011.06.006

DEFRA 2013. Making the Most of Every Drop : Consultation on Reforming the Water Abstraction Management System In Making the Most of Every Drop : Consultation on Reforming the Water Abstraction Management System ed. Food and Rural Affairs Department for Environment, 68. London.

Faysse, N., Rinaudo J.-D., Bento S., Richard A., Errahj M., Varanda M., Imache A., Dionnet M., Rollin D., Garin P., Kuper M., Maton L., and Montginoul M.. (2014). Participatory analysis for 
adaptation to climate change in Mediterranean agricultural systems: possible choices in process design. Regional Environmental Change, 14(1): 57-70. doi: 10.1007/s10113-012-0362-x

Fehr, E. and S. Gächter 2000. Cooperation and Punishment in Public Good Experiments. The American Economic Review 90: 980-993.

Figureau, A.-G, ...Montginoul M. et Rinaudo J.-D., 2012. Gestion quantitative de l'eau d'irrigation en France : bilan de l'application de la loi sur l'eau et les milieux aquatiques de 2006. In Gestion quantitative de l'eau d'irrigation en France : bilan de l'application de la loi sur l'eau et les milieux aquatiques de 2006, 50 .

Garrido, A., P. Martinez-Santos and M.R. Llamas 2005. Groundwater irrigation and its implications for water policy in semiarid countries : the Spanish experience. Hydrogeology Journal: 340-349.

Giordana, G. 2007. Expérimentation d'instruments fiscaux pour gérer l'exploitataion des aquifères côtiers. Economics, Université Montpellier I.

Giordano, M. and K.G. Villholth 2007. The Agricultural Groundwater Revolution: Opportunities and Threats to Development. Wallingford: CABI.

Gneezy, U. and A. Rustichini 2000. A Fine Is a Price. The Journal of Legal Studies 29: 1-17. doi: doi: $10.1086 / 468061$

Hatzilacou, D., G. Kallis, A. Mexa, H. Coccosis and E. Svoronou 2007. Scenario workshops: A useful method for participatory water resources planning? Water Resour. Res. 43: W06414. doi: 10.1029/2006wr004878

Hearne, R. R. and G. Donoso 2005. Water institutional reforms in Chile. Water Policy vol 53-69.

IIED 1997. Valuing the hidden harvest : Methodological Approaches for Local-Level Economic Analysis of Wild Resources. London: IIED, Sustainable Agriculture Programme.

Isik, H. B. and B. Sohngen 2003. Performance-based volontary group contracts for nonpoint source pollution. In Performance-based volontary group contracts for nonpoint source pollution, American Agricultural Economics Association Annual Meeting, 24. Montreal.

Kerr, J., M. Vardhan and R. Jindal 2012. Prosocial behavior and incentives: Evidence from field experiments in rural Mexico and Tanzania. Ecological Economics 73: 220-227. doi: http://dx.doi.org/10.1016/j.ecolecon.2011.10.031

Koundouri, P. 2004. Current issues in the economics of groundwater resource management Journal of Economic Surveys 18: 703-740.

Kuper, M, Faysse N, Hammani A., Hartani T., Marlet S., Hamamouche F. and Ameur F. (in press) Chapter 19. Liberation or anarchy? The janus nature of groundwater use on north africa's new irrigation frontiers. In Integrated Groundwater Management, eds. T. Jakeman, O. Barreteau, R. Hunt, JD Rinaudo and A. Ross: Springer.

Lenouvel, V., M. Montginoul and S. Thoyer (2011). From a blind truncheon to a one-eyed stick: testing in the lab an optional target-based mechanism adapted to groundwater withdrawals. In From a blind truncheon to a one-eyed stick: testing in the lab an optional target-based mechanism adapted to groundwater withdrawals, 18th Annual Conference of European Association of Environmental and Resource Economists, 23. Rome.

Llamas, M. R. and P. Martinez-Santos 2005. Intensive Groundwater USe : Silent Revolution and Potential Source of Conflicts. Journal of Water Resources Planning and Management: 337-341.

Lopez-Gunn, E. 2003. The Role of Collective Action in Water Governance : A Comparative Study of Groundwater User Associations in La Mancha Aquifers in Spain. Water International 28: 367-378.

Masclet, D., C. Noussair, S. Tucker and M.-C. Villeval 2003. Monetary and Nonmonetary Punishment in the Volontary Contributions Mechanism. The American Economic Review 93: 366-378. 
del Pilar Moreno-Sánchez, R., Maldonado, J.H. 2010. Evaluating the role of co-management in improving governance of marine protected areas: An experimental approach in the Colombian Caribbean. Ecological Economics 69: 2557-2567. doi: 10.1016/j.ecolecon.2010.07.032

Murphy, J. J. and J. C. Cardenas 2004. An experiment on enforcement strategies for managing a local environment resource. The Journal of Economic Education 35: 47-61.

Ostrom, E. 2000. Collective Action \& the Evolution of Social Norms. Journal of Economic Perspectives 14: 137-158.

Ostrom, E. 1990. Governing the Commons: The Evolution of Institutions for Collective Action: Cambridge University Press.

Rapoport, A. and W. T. Au 2001. Bonus and Penalty in Common Pool Resource Dilemmas under Uncertainty. Organizational Behavior and Human Decision Processes 85: 135-165. doi: 10.1006/obhd.2000.2935

Rinaudo, J. D., M. Montginoul, M. Varanda and S. Bento 2012. Envisioning innovative groundwater regulation policies through scenario workshops in France and Portugal. Irrigation and Drainage 61: 65-74. doi: 10.1002/ird.1661

Roling, N.G. and A.E. Wagemakers 2000. Facilitating Sustainable Agriculture: Participatory Learning and Adaptive Management in Times of Environmental Uncertainty: Cambridge University Press.

Romstad, E. 2003. Team approaches in reducing nonpoint source pollution. Ecological Economics 47: 71-78. doi: 10.1016/j.ecolecon.2002.10.002

Ross, A. and P. Martinez-Santos 2009. The challenge of groundwater governance: case studies from Spain and Australia. Regional Environmental Change 10: 299-310. doi: 10.1007/s10113-009-0086-8

Schlager, E. 2006. Challenges of governing groundwater in U.S. western states. Hydrogeology Journal 14: 350-360. doi: 10.1007/s10040-005-0012-1

Sefton, M., R. Shupp and J.M. Walker 2007. The effect of rewards and sanctions in provision of public goods. Economic Inquiry 45: 671-690.

Shah, T. 2012. Community response to aquifer development : distinct patterns in India's alluvial and hard rock aquifer areas Irrigation and Drainage 61: 14-25. doi: 10.1002/ird.1656

Shah, T. 2008. Taming the Anarchy: Groundwater Governance in South Asia: Taylor \& Francis.

Shah, T., A. D. Roy, A. S. Qureshi and J. X. Wang 2003. Sustaining Asia's groundwater boom: An overview of issues and evidence. Natural Resources Forum 27: 130-141. doi: 10.1111/14778947.00048

Swierzbinski, J. E. 1994. Guilty until Proven Innocent-Regulation with Costly and Limited Enforcement. Journal of Environmental Economics and Management 27: 127-146. doi: http://dx.doi.org/10.1006/jeem.1994.1030

Titmuss, R. M. 1971. The gift relationship: from human blood to social policy. New York: Pantheon books.

Travers, H., T. Clements, A. Keane and E. J. Milner-Gulland 2011. Incentives for cooperation: The effects of institutional controls on common pool resource extraction in Cambodia. Ecological Economics 71: 151-161. doi: 10.1016/j.ecolecon.2011.08.020

Van Steenbergen, F. and T. Shah 2003. Rules rather than rights: self-regulation in intensively used groundwater systems. In Intensive use of groundwater: challenges and opportunities, eds. M. Ramon llamas and Emilio Custodio, 241-256. Balkema, Lisse, The Netherlands.

Van Steenbergen, F. 2006. Promoting local management in groundwater. Hydrogeology Journal 14: 380-391.

Vatn, A. 2009. Cooperative behavior and institutions. The Journal of Socio-Economics 38: 188-196. doi: http://dx.doi.org/10.1016/j.socec.2008.07.011 
376 Velez, M. A., J. J. Murphy and J. K. Stranlund 2010. Centralized and Decentralized Management of 377 Local Common Pool Resources in the Developing World: Experimental Evidence from Fishing 378 Communities in Colombia. Economic Inquiry 48: 254-265. doi: 10.1111/j.1465-7295.2008.00125.x

379 Zafar, B. 2011. An experimental investigation of why individuals conform. European Economic 380 Review 55: 774-798. doi: 10.1016/j.euroecorev.2011.01.002 


\section{Appendix}

Table 2: Main statements by participants about Community Ties

\begin{tabular}{|c|c|c|c|}
\hline Statement & $\begin{array}{l}\text { No. of } \\
\text { wks * }\end{array}$ & Viewpoint & Opinion \\
\hline \multicolumn{4}{|l|}{ ACCEPTABILITY } \\
\hline A strategy based on self-monitoring, self-policing and denunciation is ethically unacceptable & 6 & Ethical & \multirow{3}{*}{ Opposite } \\
\hline The proposed transparency infringes on individual liberties & 4 & Ethical & \\
\hline The volume abstracted is not a good indicator of real effort and performance & 3 & Technical & \\
\hline Reallocation rules must be clear, stable over time and transparent & 7 & Technical & \multirow{6}{*}{ Neutral } \\
\hline Water reallocation must not involve financial compensation & 3 & Ethical & \\
\hline Access to individual data must be limited to the GWUA and the farmer alone & 3 & Technical & \\
\hline Only anonymous individual data or aggregate data (at the sub-basin level) should be made available & 3 & Technical & \\
\hline Transparency must be extended to other groundwater uses (urban, industrial) & 2 & Social & \\
\hline Scenario can work if the resource is a real limiting factor for farmers & 2 & Technical & \\
\hline This scenario is consistent with social/ethical values of agricultural institutions and community & 5 & Social & Support \\
\hline \multicolumn{4}{|l|}{ EFFECTIVENESS } \\
\hline The number of farmers in the basin must be limited for consensus on reallocation rules to be reached & 2 & Technical & Neutral \\
\hline Allows for an optimal resource reallocation among farmers & 6 & Economic & \multirow{3}{*}{ Support } \\
\hline It empowers farmers, reduce State interference, and promotes true self-regulation & 5 & Technical & \\
\hline Transparency is necessary to create dialog and negotiation & 3 & Technical & \\
\hline \multicolumn{4}{|l|}{ FEASIBILITY } \\
\hline Farmers have limited technical/economic room for maneuvering to reduce irrigation and return part of their allocation to the GWUA & 7 & Economic & \multirow{5}{*}{ Opposite } \\
\hline Farmers are too individualistic to contribute to the reallocation process when there will be no immediate individual benefits & 7 & Economic & \\
\hline Technical limits will impede the proper implementation of the scenario & 4 & Technical & \\
\hline Transparency will not be a deterrent in drought years or for farmers who do not care about their reputation & 3 & Social & \\
\hline Farmers will be reluctant to give back water given the uncertainty of their own crop requirements & 2 & Economic & \\
\hline \multicolumn{4}{|l|}{ UNDESIRABLE EFFECTS } \\
\hline Conflicts will arise owing to (1) transparency/self-policing and (2) unbalanced efforts and benefits in the reallocation process. & 5 & Social & Opposite \\
\hline There must be farm heterogeneity in order to create complementarities in water requirements between farmers & 2 & Technical & \multirow{2}{*}{ Neutral } \\
\hline GWUA must have technical and legal capacity for implementing transparency and agreed reallocation rules & 2 & Technical & \\
\hline
\end{tabular}

*: number of workshops (out of 16 ) in which the statement was quoted at least once. 
Author-produced version of the article published in Ecological Economics, 2015, №119, p.147-157.

The original publication is available at http://www.sciencedirect.com

Doi: 10.1016/j.ecolecon.2015.08.011

Table 3: Main statements by participants about Penalties and Payments (P\&P)

\begin{tabular}{|c|c|c|c|}
\hline Statement & $\begin{array}{l}\text { No. of } \\
\text { wks * }\end{array}$ & Viewpoint & Opinion \\
\hline \multicolumn{4}{|l|}{ ACCEPTABILITY } \\
\hline Principles underlying P\&P (monetizing water, redistributing revenues, penalizing a productive activity,...) will hardly be accepted by farmers & 11 & Ethical & \multirow{7}{*}{ Opposite } \\
\hline $\begin{array}{l}\text { P\&P will generate unfair distribution of benefits and handicaps, owing to farm heterogeneity (farm size, crop, soil, water needs, recent } \\
\text { investments,...) and weather variability }\end{array}$ & 10 & Economic & \\
\hline P\&P introduces a monetary dimension which should not exist in water management & 6 & Ethical & \\
\hline Other economic regulation through insurance or standard volumetric pricing would be preferable to P\&P & 5 & Economic & \\
\hline $\begin{array}{l}\text { Penalty revenue should be used to support collective projects (development of water resources and water conservation programs) rather } \\
\text { than to offer individual payments }\end{array}$ & 5 & Institutional & \\
\hline P\&P are useless as farmers will spontaneously comply with their allocations & 5 & Technical & \\
\hline P\&P will increase constraints and work load on the farm & 3 & Economic & \\
\hline Farmers endowed with excessive initial allocation should not be rewarded if they reduce abstraction (illegitimate reward) & 4 & Ethical & \multirow{7}{*}{ Neutral } \\
\hline P\&P must be implemented by GWUA (with increased powers), not by government agencies & 4 & Institutional & \\
\hline P\&P will only be accepted in water-scarce basins where farmers are already used to paying water fees & 4 & Social & \\
\hline Payments do not reward a real effort, they should be removed. Penalties are needed & 3 & Ethical & \\
\hline Amounts of P\&P payments must provide incentives without hindering agricultural competitiveness & 2 & Economic & \\
\hline P\&P must also apply to other groundwater users (urban, industrial) to be accepted by farmers & 2 & Social & \\
\hline P\&P must apply only to situations where available groundwater resource is known with accuracy & 2 & Technical & \\
\hline The system will be better accepted than taxes charged by government because money stays within the farming community & 3 & Social & \multirow{3}{*}{ Support } \\
\hline It is necessary and legitimate to compensate financial losses incurred by farmers for reducing abstraction & 2 & Economic & \\
\hline P\&P's theoretical bases are easy to understand and likely to be accepted by the farming community & 2 & Technical & \\
\hline \multicolumn{4}{|l|}{ EFFECTIVENESS } \\
\hline Penalties will not stop farmers from exceeding their individual allocation during droughts and for high-value crops & 12 & Economic & \multirow{5}{*}{ Opposite } \\
\hline Payments will not provide sufficient incentive as they are unknown at the planting stage & 9 & Economic & \\
\hline Penalty level is not high enough to affect the relative profitability of crops and make farmers change practices & 8 & Economic & \\
\hline Payments will not yield significant water saving as farmers have limited technical/economic room for maneuver to reduce irrigation & 8 & Technical & \\
\hline P\&P will not work in drought years as a majority of farmers will exceed their allocation to save their crops & 7 & Economic & \\
\hline Financial incentives could be combined with volumetric penalty (reduction of the following year's allocation) & 4 & Economic & \multirow{2}{*}{ Neutral } \\
\hline Penalty could be volumetric (reduction of individual allocation the following year) rather than financial & 4 & Ethical & \\
\hline
\end{tabular}


Author-produced version of the article published in Ecological Economics, 2015, $N^{\circ} 119$, p.147-157.

The original publication is available at http://www.sciencedirect.com

Doi: 10.1016/j.ecolecon.2015.08.011

\begin{tabular}{|c|c|c|c|}
\hline Statement & $\begin{array}{l}\text { No. of } \\
\text { wks * }\end{array}$ & Viewpoint & Opinion \\
\hline The amount of payment should be set in advance and not dependent on the revenue from penalties (uncertainty) & 3 & Economic & \\
\hline $\begin{array}{l}\text { Penalty amount could be adjusted based on annual context to enhance its incentive effect (indexed on the mean of effective abstractions, } \\
\text { river flow, climate, crop prices, etc.) }\end{array}$ & 3 & Economic & \\
\hline $\begin{array}{l}\text { The period over which payments and penalties must be calculated and charged must be adapted to each groundwater basin's } \\
\text { characteristics (weekly, semiannual, annual, multiannual, ,...) }\end{array}$ & 3 & Technical & \\
\hline P\&P will provide the necessary incentive for farmers to adjust crop choices and irrigation practices & 8 & Economic & \multirow{3}{*}{ Support } \\
\hline P\&P will enhance flexibility compared to a fixed quota system with benefits to farmers & 6 & Technical & \\
\hline A penalty system is necessary as behaviors change only under a repressive framework & 4 & Economic & \\
\hline \multicolumn{4}{|l|}{ FEASIBILITY } \\
\hline $\begin{array}{l}\text { GWUAs will face technical difficulties in implementing P\&P (calculating payments, collecting penalties, balancing water and financial budget, } \\
\text { etc) }\end{array}$ & 6 & Technical & \multirow{3}{*}{ Opposite } \\
\hline The incentive effect will be hindered by the complex calculations both farmers and managers will have to make before taking decisions & 5 & Technical & \\
\hline Uncertainties (on climate, others' behavior, payment amount, etc.) will impede farmers in optimizing decisions and strategies & 4 & Economic & \\
\hline Farmers will respond to incentives and adopt long term change only if the external context is not too uncertain & 3 & Economic & Neutral \\
\hline \multicolumn{4}{|l|}{ UNDESIRABLE EFFECTS } \\
\hline P\&P may encourage opportunistic behaviors from farmers to obtain the maximum payment & 7 & Economic & \multirow{6}{*}{ Opposite } \\
\hline The financial dimension of P\&P may create undesirable drifts (pressure on GWUA, conflicts among farmers, emergence of black market, etc) & 7 & Ethical & \\
\hline P\&P may have negative impact on local economy and agricultural competitiveness & 6 & Economic & \\
\hline P\&P may lead to unexpected excess pumping and associated environmental damage & 6 & Technical & \\
\hline P\&P will have negative impacts on local economy owing to crop switch (reduced competitiveness, insufficient supply of related industries) & 5 & Economic & \\
\hline P\&P may increase fraud (using illegal wells or tampering with metering device) & 3 & Technical & \\
\hline
\end{tabular}

*: number of workshops (out of 16 ) in which the statement was quoted at least once. 
Author-produced version of the article published in Ecological Economics, 2015, №119, p.147-157.

The original publication is available at http://www.sciencedirect.com

Doi: 10.1016/j.ecolecon.2015.08.011

Table 4: Main statements by participants about the Joint Liability contract

\begin{tabular}{|c|c|c|c|}
\hline Statement & $\begin{array}{l}\text { No. of } \\
\text { wks* }\end{array}$ & Viewpoints & Opinion \\
\hline \multicolumn{4}{|l|}{ ACCEPTABILITY } \\
\hline Group management brings too many additional constraints which jeopardize farmers' individual freedom and adaptive capacity & 3 & Ethical & \multirow{2}{*}{ Opposite } \\
\hline The Joint Liability contract may lead to the emergence of collective farms (negative perception) & 3 & Social & \\
\hline $\begin{array}{l}\text { The contract must be accompanied by a mediator, from outside the group, to facilitate the resolution of problems and potential conflicts } \\
\text { among members }\end{array}$ & 4 & Institutional & \multirow{3}{*}{ Neutral } \\
\hline Contract's internal rules must be clearly defined within the groups & 4 & Institutional & \\
\hline The adoption of the contract requires a switch in farmers' mentalities (from an individualistic to a collective reasoning) & 3 & Social & \\
\hline The principles underlying the Joint Liability contract are in line with the social and ethical values of the farming community & 9 & Ethical & \\
\hline The Joint Liability contract will give a formal framework to existing informal agreements over water use & 5 & Institutional & Support \\
\hline Collective management will convey a positive image of farmers towards both administration and society & 3 & Social & \\
\hline \multicolumn{4}{|l|}{ EFFECTIVENESS } \\
\hline Farmers are too individualistic. so that few will sign a Joint Liability contract & 12 & Social & \multirow{6}{*}{ Opposite } \\
\hline Self-policing will not be effective & 6 & Social & \\
\hline Benefits for entering a contract are too low, particularly for farmers who already comply with their allocation & 5 & Economic & \\
\hline The joint liability and the collective penalty will act as deterrents to entering a contract & 4 & Social & \\
\hline At the basin scale, there will be few complementarities to be exploited in contracts & 3 & Economic & \\
\hline $\begin{array}{l}\text { The contract will not be effective in extreme climatic or economic conditions since selfish behaviors will overwhelm pro-social and } \\
\text { cooperative attitudes }\end{array}$ & 3 & Social & \\
\hline Group size must be limited to ensure effective solidarity & 9 & Technical & \multirow{9}{*}{ Neutral } \\
\hline Heterogeneity (of crops, practices, farm orientation, weather conditions) is essential for the contract to be beneficial to members & 9 & Technical & \\
\hline Crop rotations must be jointly planned within the group for inter-annual optimization of water use & 6 & Technical & \\
\hline $\begin{array}{l}\text { Contracts will be beneficial only to farmers with particular crop specializations or farm structure (growing seeds, having simple crop rotation } \\
\text { or about to retire) }\end{array}$ & 5 & Economic & \\
\hline Group's size must be large to have a significant impact on water resources & 4 & Institutional & \\
\hline Farmers must previously know each other and be used to working together if they are sign such a contract & 4 & Social & \\
\hline Contracts will be signed only by friends/colleagues/neighbors (a minority of farmers) & 4 & Social & \\
\hline The Joint Liability contract must remain a voluntary option & 3 & Institutional & \\
\hline Successful implementation of a few contracts is necessary to induce a snowball effect & 3 & Social & \\
\hline The system will create reallocation opportunities among heterogeneous groups of farmers & 5 & Economic & Support \\
\hline
\end{tabular}


Author-produced version of the article published in Ecological Economics, $2015, N^{\circ} 119$, p.147-157.

The original publication is available at http://www.sciencedirect.com

Doi: 10.1016/j.ecolecon.2015.08.011

\begin{tabular}{|c|c|c|c|}
\hline Statement & $\begin{array}{l}\text { No. of } \\
\text { wks* }\end{array}$ & Viewpoints & Opinion \\
\hline By mutualizing water allocation, the Joint Liability contract reduces individual constraints and risk exposure & 5 & Economic & \\
\hline The Joint Liability contract should be made mandatory & 5 & Institutional & \\
\hline Social interactions (dialog, solidarity, voluntary commitment...) will ensure the contract's success & 5 & Social & \\
\hline The Joint Liability contract will stabilize and increase farmers' income & 3 & Economic & \\
\hline The Joint Liability contract offers flexibility & 3 & Economic & \\
\hline By mutualizing water allocation, the contract allows every drop to be used & 3 & Economic & \\
\hline \multicolumn{4}{|l|}{ FEASIBILITY } \\
\hline Few farmers will be able to reduce water use since their room for maneuver is limited (technically and economically) & 6 & Technical & \\
\hline Adding another level of organization increases the complexity of groundwater governance & 5 & Institutional & Opposite \\
\hline Contract implementation will be hindered by technical limits, e.g., group and hydrogeological boundaries are unlikely to fit & 4 & Technical & \\
\hline Collective management is already experienced by farmers on other resources and does work well & 12 & Social & \\
\hline $\begin{array}{l}\text { Self-regulation has proven advantageous for users and effective in managing common resources (labor, machinery, surface water } \\
\text { resources) }\end{array}$ & 9 & & Support \\
\hline \multicolumn{4}{|l|}{ UNDESIRABLE EFFECTS } \\
\hline Conflicts may emerge within groups under particular conditions (drought years, collective sanction applied ...) & 11 & Social & \multirow{3}{*}{ Opposite } \\
\hline Individual interests may prevail over collective ones so that group allocations may be exceeded & 4 & Economic & \\
\hline $\begin{array}{l}\text { Conflicts may emerge between contract members and non-members since the latter may jeopardize the former's positive impact on the } \\
\text { environment }\end{array}$ & 4 & Social & \\
\hline
\end{tabular}

